\title{
MERANCANG MODEL BLENDED LEARNING
}

\author{
DESIGNING BLENDED LEARNING MODEL
}

\author{
Uwes Anis Chaeruman \\ Pustekkom Kemdikbud \\ Jalan RE Martadinata, Ciputat, Tangerang Selatan, Banten, Indonesia \\ uwes.anis@kemdikbud.go.id
}

diterima: 10 September 2013; dikembalikan untuk direvisi: 16 September 2013; disetujui: 25 September 2013

\begin{abstract}
Abstrak: Dalam era komunikasi instan dewasa ini, cara belajar dan proses pembelajaran telah berubah. Kondisi ini membawa pembelajaran ke era e-learning di mana upaya belajar dan membelajarkan dapat difasilitasi dengan teknologi informasi dan komunikasi. Mengkombinasikan teknologi informasi dan komunikasi yang tepat (blended learning) merupakan salah satu isu penting dalam merancang e-learning yang baik. Oleh karena itu diperlukan semacam panduan (framework) yang dapat menjadikan acuan dalam memilih dan menentukan blended learning yang tepat sesuai kondisi dan tujuan yang ingin dicapai. Artikel ini mencoba memberikan framework untuk menjawab permasalahan tersebut. Framework yang coba ditawarkan dalam artikel ini mengacu pada konsep e-learning, empat kuadran seting belajara menurut Noord, dua kontinum strategi pembelajaran menurut Smaldino dkk., dan empat standar proses pembelajaran yang penulis adaptasi dari Horton. Framewrok tersebut adalah bahwa dam merancang blneded learning perlu mempertimbangkan beberapa unsur sebagai berikut: 1) upaya memfasilitasi pengalaman belajar sebagai esensi dari e-learning; 2) optimalisasi empat standar proses pembelajaran dalam konteks e-learning; 3) pemilihan dan penentuan strategi pembelajaran yang tepat; dan 4) pemilihan dan penentuan teknologi dan tool TIK yang tepat dalam empat kuadran seting belajar.
\end{abstract}

Kata Kunci: e-learning, blended learning, synchronous learning, asynchronous learning

Abstract: In the era of instant communication, today, learning and instructional process has changed. This condition has led learning into a new era called e-learning, where learning process can be facilitated with proper use of information and communication technology. Combining information and communication technology appropriately to facilitate learning has become an impportant issue in e-learning design context. Therefore, we need such a kind of framework as a guidance in selecting and determining the appropritae blended learning strategy to address the learning objectives to be achieved. The framework offered in this article refered to the essential concept of e-learning itself, four quadrants of learning seting offered by Noord, two continuum of instructional strategy offerd by Smaldino et. al., and four standard of e-learning process adapted by author from the work of Norton. The framework offered are that in designing blended learning, we should consider the following aspects: 1) efforts to facilitate learning experiences as the essence of e-learning; 2) optimalization of the four learning process standard in the context of e-learning; 3) selection and determination of appropriate learning strategies; and 4) selection and determination of apropriate learning seting and ICTS used in four quadrants of learning seting.

Keywords: e-learning, blended learning, synchronous learning, asynchronous learning 


\section{Pendahuluan}

Dewasa ini, ilmu pengetahuan dan teknologi, khususnya teknologi informasi dan komunikasi telah berkembang dengan pesat. Hal ini, terutama dipengaruhi oleh keberadaan teknologi koneksi internet dan protokol pencari universal yang dikenal dengan istilah world wide web (www) dengan segala tool dan aplikasinya yang memungkinkan terjadinya aktifitas kolaboratif dan saling berbagi informasi secara luas tanpa terhalang oleh batas wilayah dan waktu (Dabbagh \& Ritland, 2005). Tidaklah heran kalau era informasi dewasa ini juga dikenal sebagai era komunikasi instan dimana semua orang dapat berkomunikasi dengan mudah, cepat dan relative murah.

Potensi teknologi informasi dan komunikasi yang menjanjikan tersebut, sejak $10-15$ tahun belakangan telah berpengaruh terhadap berbagai aspek kehidupan manusia, tak terkecuali pendidikan. (Holmes \& Gardner, 2006). Sejak saat itu, telah bermunculan istilah-istilah terkait dengan pembelajaran yang menerapkan teknologi informasi dan komunikasi dengan aneka ragam terminologi seperti stand alone course, virtual classroom, embedded learning, blended learning, mobile learning, (Horton, 2006) networked-learning, computer-assisted learning, web-based instruction, computer-mediated learning, online learning (Littlejohn \& Pegler, 2007). Beberapa istilah tersebut mengacu pada konsep pembelajaran berbantuan teknologi elektronik yang dikenal dengan istilah e-learning. Istilah e-learning itu sendiri sendiri baru populer sejak tahun 2002 yang kemudian menjadi istilah generik yang memayungi semua istilah-istilah seperti tersebut di atas yang telah muncul beberapa tahun sebelumnya (Littlejohn \& Pegler, 2007) . Dalam konteks e-learning ini, salah satu trend yang muncul dan menarik untuk diterapkan adalah konsep blended learning .

Disamping potensinya yang luar biasa, penerapan e-learning masih memiliki tantangan besar. Salah satu tantangan tersebut adalah bukan terletak pada aneka ragam teknologi informasi dan komunikasi yang dapat digunakan, tapi terletak pada bagaimana merancang (design) kombinasi penerapan teknologi informasi dan komunikasi yang tepat untuk proses pembelajaran tertentu. Littlejohn menyebutnya dengan istilah design of blended e-learning (Littlejohn \& Pegler, 2007).
Senada dengan Littlejohn, Khan juga mendefinisikan e-Learning dengan mencantumkan secara eksplisit kalimat pembelajaran yang perlu dirancang dengan baik (well-designed learning environment) (Khan, 2005). Kondisi seperti tersebut menunjukkan pentingnya peran rancangan sistem pembelajaran e-learning (elearning system design) yang dapat memberikan panduan bagi pihak terkait dalam mengimplementasikan e-Learning atau blended learning yang efektif. Trend ini merupakan salah satu domain kajian disiplin ilmu teknologi pendidikan.

Menjawab permasalahan seperti dijelaskan di atas, penulis ingin mencoba memberikan suatu formula atau semacam preskripsi dalam merancang kombinasi penerapan teknologi informasi dan komunikasi yang tepat (blended learning design) untuk suatu konteks pembelajaran tertentu. Tulisan ini akan membahas konsep seting belajar kaitannya dengan strategi pembelajaran dan pemilihan serta penentuan tool dan aplikasi TIK yang tepat sesuai dengan kondisi dan kompetensi tertentu yang ingin dicapai.

\section{Kajian Literatur dan Pembahasan \\ Blended Learning: Bukan sekedar Kombinasi antara Pembelajaran Tatap Muka dan Online! Mengenal Lebih Dekat tentang e-Learning}

Ada banyak istilah atau terminologi yang mengacu pada kata e-Learning, seperti virtual learning, online learning, virtual class, e-training, dan lain-lain. Di samping itu, sulit juga mencari definisi yang jelas tentang e-Learning . Tapi, satu hal yang jelas, e-learning merupakan istilah generik dari pendayagunaan teknologi elektronik untuk pembelajaran. Stockley mendefinisikan e-learning sebagai penyampaian program pembelajaran, pelatihan atau pendidikan dengan menggunakan sarana elektronik seperti komputer atau alat elektronik lain seperti telepon genggam dengan berbagai cara untuk memberikan pelatihan, pendidikan atau bahan ajar (Stockley, 2010). Dalam hal ini Stockley menegaskan e-learning sebagai penyampaian program pembelajaran atau pelatihan dengan memanfaatkan sarana elektronik. Jadi, huruf "e" pada kata e-learning merujuk pada penggunaan sarana elektronik untuk pembelajaran. 
Sementara itu, Naidu menyatakan bahwa e-learning, secara fundamental adalah proses pendidikan yang memanfaatkan teknologi informasi dan komunikasi untuk menjembatani kegiatan belajar dan pembelajaran baik secara asinkronous maupun sinkronous (Naidu, 2006). Jadi, e-Learning diartikan sebagai penggunaan jaringan teknologi informasi dan komunikasi dalam proses pembelajaran. Definisi ini menegaskan bahwa seting belajar dalam konteks e-learning terjadi baik secara sinkronous dan asinkronous yang dijembatani oleh penggunaan jaringan teknologi informasi dan komunikasi.

Horton, lebih tegas lagi mendefinisikan e-learning yang lebih menekankan pada pentingnya peristiwa belajar terjadi dengan bantuan teknologi elektronik tersebut. Ia mendefinisikan e-learning sebagai penggunaan teknologi informasi dan komputer untuk menciptakan pengalaman belajar (Horton, 2006). Jadi, menurut Horton, terjadinya pengalaman belajar melalui teknologi informasi dan komputer tersebut hendaknya menjadi fokus utama.

Senda dengan Horton, Khan menjelaskan bahwa e-learning dapat dipandang sebagai pendekatan inovatif dalam menyampaikan pembelajaran yang telah dirancang dengan baik, berpusat pada pemelajar, interaktif dan dapat memfasilitasi pembelajaran untuk siapa saja, dimana saja dan kapan saja dengan memanfaatkan atribut-atribut dan sumber dari beragam teknologi digital bersama dengan bahan ajar lain yang tepat untuk lingkungan belajar yang bersifat terbuka, terdistribusi dan fleksibel (Khan, 2005). Dalam hal ini, Khan menekankan bahwa dengan e-learning memungkinkan pembelajaran terjadi kapan saja dan dimana saja, tidak terikat oleh waktu dan tempat.

Mengacu pada beberapa definisi yang telah dikemukakan di atas, dapat disimpulkan bahwa eLearning merupakan istilah yang generik dan luas yang menjelaskan tentang penggunaan berbagai teknologi elektronik untuk menyampaikan pembelajaran. Lebih tepatnya, bukan hanya sekedar untuk menyampaikan pembelajaran, tapi lebih jauh untuk menciptakan pengalaman belajar yang optimal. Teknologi elektronik tersebut dapat berupa komputer, internet maupun intranet serta teknologi elektronik lain seperti audio/ radio, dan video/televisi.

e-Learning sebagai penerapan teknologi elektronik untuk menciptakan pengalaman belajar (pembelajaran), tidak dapat dipandang sebagai sesuatu yang diskrit. Tapi, dalam prakteknya, e-learning merupakan suatu kontinum. Rashty (1999) seperti yang dikutip oleh Noirid mengklasifikasikan kontinum e-learning kedalam tiga kategori seperti gambar 1 (Noirid, 2007).

Diagram (gambar 1) menggambarkan kontinum elearning mulai dari "adjunct", "blended/mixed", dan "fully online". Kategori adjunct adalah proses pembelajaran tradisional plus. Artinya pembelajaran tradisional yang ditunjang dengan sistem penyampaian secara online sebagai pengayaan. Keberadaan sistem penyampaian secara online merupakan suatu tambahan. Contoh untuk menunjang pembelajaran di kelas, seorang guru/ dosen menugaskan siswa/mahasiswanya untuk mencari informasi dari internet.

Sementara, kategori mixed/blended menempatkan sistem penyampaian secara online sebagai bagian yang tidak terpisahkan dari proses pembelajaran secara keseluruhan. Artinya baik proses tatap muka maupun pembelajaran secara online merupakan satu kesatuan utuh. Berbeda dengan model adjunct yang hanya menempatkan sistem penyampaian online sebagai
Adjunct

$$
\text { C }
$$

Mixed/Blended

Continuing tradisional learning procceses, but enhancing them or extending them beyond classroom hour with online resources particularly using computer mediated communication (CMC).

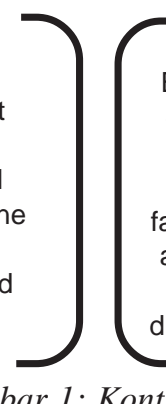

Becoming as integral part of curricula. Mixing delivery of content, $\mathrm{CMC}$, or online collaboration with face to face session. Determining the appropriateness of online or face to face to deliver different aspects of curricula.

\section{Fully Online}

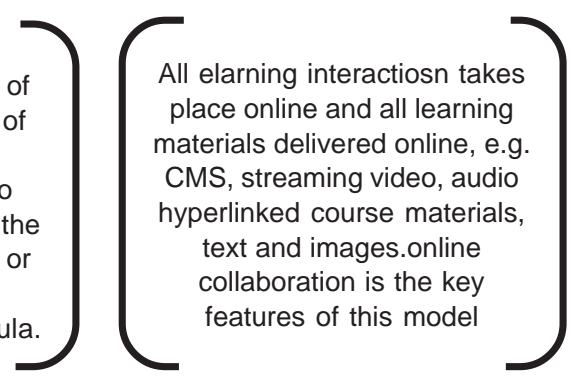

Gambar 1: Kontinum e-Learning diadaptasi dari Rashty

(1999) oleh Noirid (2007). 
tambahan. Dalam model blended, tentu saja masalah relevansi topik pelajaran mana yang dapat dilakukan secara online dan mana yang dilakukan secara tatap muka (tradisional) menjadi faktor pertimbangan penting dalam penyesuaian dengan tujuan pembelajaran, materi pembelajaran, karakteristik siswa maupun kondisi yang ada.

Lain halnya dengan kategori fully online, semua interaksi pembelajaran dan penyampaian bahan belajar terjadi secara online. Contoh, bahan belajar berupa video diunggah dan diterima via internet, atau pembelajaran ditautkan (linked) melalui hyperlink ke sumber lain yang berupa teks atau gambar. Ciri utama model ini adalah terjadinya pembelajaran kolaboratif secara online. Tidak ada tatap muka sama sekali.

Pada dasarnya, baik online penuh maupun pembelajaran tatap muka memiliki kelebihan dan kelemahan masing-masing. Kelemahan pada online learning bisa diatasi oleh kelebihan pada pembelajaran tatap muka. Begitu pula sebaliknya, kelemahan pada tatap muka dapat diatasi oleh kelebihan online learning. Oleh karena itu, khususnya di perguruan tinggi, penerapan blended learning lakan ebih tepat, mengingat kuliah tatap muka masih merupakan kewajiban.

\section{Lebih Jauh tentang Blended Learning}

Blended learning, secara umum dipahami sebagai proses pembelajaran yang mengkombinasikan antara pembelajaran tatap muka dan online. Menurut Thorne, ada dasarnya keberadaan blended learning merupakan suatu respon terhadap keberadaan kemajuan teknologi online dengan praktek terbaik pembelajaran tradisional. la menyatakan bahwa blended learning adalah suatu peluang upaya mengintegrasikan kemajuan inovasi dan teknologi yang ditawarkan secara online dengan interaksi dan partisipasi yang ditawarkan dalam pembelajaran tradisional (Thorne, 2003).

Watson menjelaskan blended learning sebagai konvergensi antara pembelajaran online dengan pembelajaran tatap muka. Secara tegas la menyatakan bahwa blended learning adalah pembelajaran yang mengkombinasikan komponen terbaik pembelajaran online dan pembelajaran tatap muka (Watson, 2008, p. 4). Hal senada juga diungkapkan oleh Graham yang mendefinisikan blended learning sebagai kombinasi pembelajaran dari dua model proses belajar-mengajar yang secara historis berbeda, yaitu antara sistem pembelajaran tradisional (tatap muka) dan sistem pembelajaran terdistribusi (distributed learing system) (Bonk \& Graham, 2006). Sistem pembelajaran terdistribusi terjadi karena adanya pemanfaatan potensi yang luar biasa dari teknologi elektronik, khususnya komputer dan internet sehingga memungkinkan siapa saja dapat belajar kapan saja dan dimana saja. Lebih jauh Bonk dan Graham menyatakan bahwa blended learning pada dasarnya mengkombinasikan aspek positif dari dua jenis lingkungan belajar yaitu pembelajaran di kelas dan e-learning (Bonk \& Graham, 2006). Jadi, sama seperti telah diungkapkan sebelumnya bahwa dengan blended learning kelemahan pada pembelajaran tatap muka dapat diatasi dengan kelebihan pembelajaran online. Begitu pula sebaliknya, kelemahan online learning dapat diatasi dengan kelebihan pembelajaran tatap muka. Antara keduanya, pembelajaran tatap muka dan pembelajaran online, pada dasarnya merupakan suatu kesinambungan historis antara cara tradisional dengan cara modern.

Khan, menjelaskan blended learning dari perspektif yang lebih luas. la menyatakan bahwa blended learning merupakan kombinasi strategi penyampaian materi yang tepat dalam format yang tepat untuk orang yang tepat pada saat yang tepat. Blended learning mengkombinasikan beragam media penyampaian yang dirancang untuk saling melengkapi satu sama lain dan mendorong terjadinya proses belajar yang optimal (Khan, 2005). Dengan demikian, dalam mendesain blended learning, ketepatan pemilihan kombinasi media penyampaian baik dalam seting pembelajaran tradisional maupun online menjadi penting. Dimana, fokus utamanya adalah terjadinya belajar secara optimal. Disamping itu, Khan menyatakan bahwa dalam blended learning meliputi kombinasi beragam aktifitas meliputi tatap muka dalam kelas, live e-learning, dan belajar mandiri. Semuanya merupakan kombinasi antara pembelajaran tradisional (dipandu oleh guru/ dosen), pembelajaran online sinkronous, belajar mandiri secara asinkronous dan pembelajaran terstruktur yang didasarkan pada pengalaman pemelajar dan mentor (Khan, 2005).

Howard menjelaskan bahwa blended learning tepat 
dua seting pembelajaran yaitu pembelajaran asinkronous dan pembelajaran sinkronous. Pembelajaran sinkronous adalah proses belajar yang terjadi secara simultan pada saat yang sama antara pemelajar dengan tutor/guru/ dosen, walaupun tidak harus terjadi di tempat yang sama (Littlejohn \& Pegler, 2007). Pembelajaran sinkronous terdiri dari dua tipe. Tipe pertama adalah pembelajaran tatap muka dalam kelas (Smaldino, et al., 2008). Khan mengistilahkannya sebagai pembelajaran sinkronous secara fisik (synchronous physical format) (Khan, 2005). Tipe sinkronous tatap muka langsung atau sinkronous secara fisik terjadi secara simultan pada saat yang sama di tempat yang sama. Contohnya adalah pembelajaran tatap muka di kelas, penelitian di laboratorium, karyawisata, presentasi dan diskusi kelompok dalam kelas, dan segala metode pembelajaran tradisional lainnya. Tipe kedua adalah sinkornous online), atau disebut juga sinkronous kolaborasi virtual (Staley, 2007) seperti konferensi audio/video, chatting, pembelajaran online langsung (live), instant messenger dan lain-lain.

Pembelajaran asinkronous adalah aktifitas pembelajaran yang memungkinkan pemelajar berbeda untuk mengalami materi ajar yang sama pada waktu dan tempat yang berbeda (Smaldino, et al., 2008).
Staley mengklasifikasikan aktifitas pembelajara asinkronous kedalam dua kategori, yaitu asinkronous kolaboratif (seperti forum diskusi online, mailinglist, e-mail, dll) dan asinkronous mandiri (seperti simulasi, tes online, searching materi, materi dalam bentuk pdf, doc, html, video, animasi, dll.) (Staley, 2007).

Jika diilustrasikan kedalam suatu tabel maka seting dan aktifitas belajar dalam konteks blended learning dapat digambarkan pada tabel 1 .

\section{Strategi Pembelajaran}

Strategi pembelajaran dapat diklasifikasikan kedalam berbagai kategori dengan cara yang berbeda menurut pendapat pakar yang berbeda. Dalam tulisan ini, penulis mengacu klasifikasi strategi pembelajaran menurut Smaldino $d k k$. yang membaginya kedalam dua kategori, yaitu strategi pembelajaran yang berpusat pada siswa dan strategi pembelajaran yang berpusat pada guru (Smaldino, et al., 2008). Strategi pembelajaran tersebut dapat digambarkan seperti dalam tabel 2 .

Lebih jauh, Smaldino menjelaskan kapan strategi pembelajaran tersebut cocok digunakan seperti dalam tabel 3 (Smaldino, et al., 2008).

Tabel 1:Diadaptasi dari Khan (2005) dan Staley (2007)) oleh Chaeruman, 2013

\begin{tabular}{llll}
\hline & Pembelajaran Sinkronous & & Pembelajaran Asinkronous \\
\hline Tatap Muka Langsung & Sinkronous Maya & Asinkronous Kolaboratif & Asinkronous Mandiri \\
\hline * Ceramah dosen & $*$ Konferensi audio & * Forum diskusi & * Tes/asesmen online \\
* Penelitian di lab. & $*$ Konferensi video & * e-mail & * Mengerjakan tugas \\
* Diskusi kelompok. & $*$ Chatting & * mailinglist (list serv) & * Mearching materi \\
* Karyawisata(semua & & $*$ wiki & berbagai format (teks, grafis, \\
metode pembelajaran & & & audio, video, animasi, dll) \\
tradisional) & & &
\end{tabular}

Tabel 2: Strategi pembelajaran

\begin{tabular}{ll}
\hline $\begin{array}{l}\text { No. Strategi berpusat } \\
\text { pada guru }\end{array}$ & $\begin{array}{c}\text { Strategi berpusat } \\
\text { pada siswa }\end{array}$ \\
\hline 1. Presentasi & Diskusi \\
2. Demonstrasi & Permainan dan Simulasi \\
3. Drill \& Praktek & Pemecahan Masalah \\
4. Tutorial & Pembelajaran Kooperatif \\
\hline
\end{tabular}

Memilih dan Menentukan Kombinasi Blended Learning yang Tepat

Seperti telah dibahas di atas, bahwa blended learning pada dasarnya adalah kombinasi yang tepat pemilihan dan penentuan metode serta tool dan teknologi yang relevan dalam seting belajar sinkronous dan asinkronous sesuai dengan kompetensi yang hendak dicapai. Pertanyaan berikutnya adalah, patokan apa yang menjadi dasar pemilihan mana yang harus sinkronous dan mana yang harus asikronous. Dalam 
Tabel 3 (Smaldino, et al., 2008).

\begin{tabular}{lll}
\hline No. & Strategi Pembelajaran & diterapkan ketika ... \\
\hline 1. & Presentasi & pemelajar memerlukan penjelasan secara umum. \\
\hline 2. & Demonstrasi & pemelajar memerlukan proses mengamati terlebih dahulu sebelum mencoba atau menerapkan. \\
\hline 3. & Drill \& Praktek & pemelajar perlu mereview, mengulang, menirukan dan mempraktekkan. \\
\hline 4. & Tutorial & pemelajar memerlukan bimbingang khusus dalam hal-hal tertentu. \\
\hline 5. & Diskusi & pemelajar perlu berikir kritis, mendalami konsep atau prinsip. \\
\hline 6. & Permainan dan & pemelajar perlu mereview, menerapkan dan mempraktekkan atau mengaplikasikan dalam situasi \\
& Simulasi & senyatanya. \\
\hline 7. & Pemecahan & pemelajar perlu berlatih menerapkan konsep dan prinsip untuk memecahkan masalah \\
& Masalah & \\
\hline 8. & Pembelajaran & pemelajar perlu berlatih menerapkan konsep, prinsip untuk memcahkan masalah secara kolaboratif. \\
& Kooperatif & \\
\hline
\end{tabular}

konteks ini, penulis menganjurkan untuk menggunakan konsep 4 kuadran seting belajar menurut Noord yang dikutip oleh Staley (Staley, 2007) dan klasifikasi strategi pebelajaran menurut Smaldino $d k k$. dan standar proses pembelajaran dalam konteks lingkungan e-learning yang penulis adaptasi dari Horton (2006).

\section{Empat Kuadran Seting Belajar}

Empat kuadran seting belajar tersebut, penulis adaptasi dari Noord dalam Staley (2007) seperti digambarkan dalam diagram 1.

Mengacu pada diagram di atas, terlihat jelas bahwa terdapat empat kuadran seting belajar sebagai berikut: Sinkronous langsung (live synchronous); suatu kondisi dimana belajar terjadi pada waktu dan tempat bersamaan. Dilihat dari dimensi tempat dan waktu terjadi pada saat bersamaan. Seting belajar seperti ini terjadi dalam pembelajaran konvensional, dimana antara peserta belajar dengan guru/dosen/tutor berada pada tempat yang sama dan waktu yang sama, belajar didalam kelas. Contoh metode pembelajaran yang terjadi dalam konteks ini adalah cerama, diskusi kelompok, praktek laboratorium, karyawisata, dan lainlain.

Sinkronous Maya (virtual synchronous); suatu kondisi dimana belajar terjadi pada waktu bersamaan (real time) di tempat yang berbeda-beda satu sama lain. Dalam konteks ini, belajar terjadi dalam dimensi waktu yang sama, tapi dimensi ruang/tempat yang berbeda-beda satu sama lain. Contoh metode

Diagram 1: Diadaptasi dari Noord dalam Staley 2007 oleh Uwes A. Chaeruman, 2013

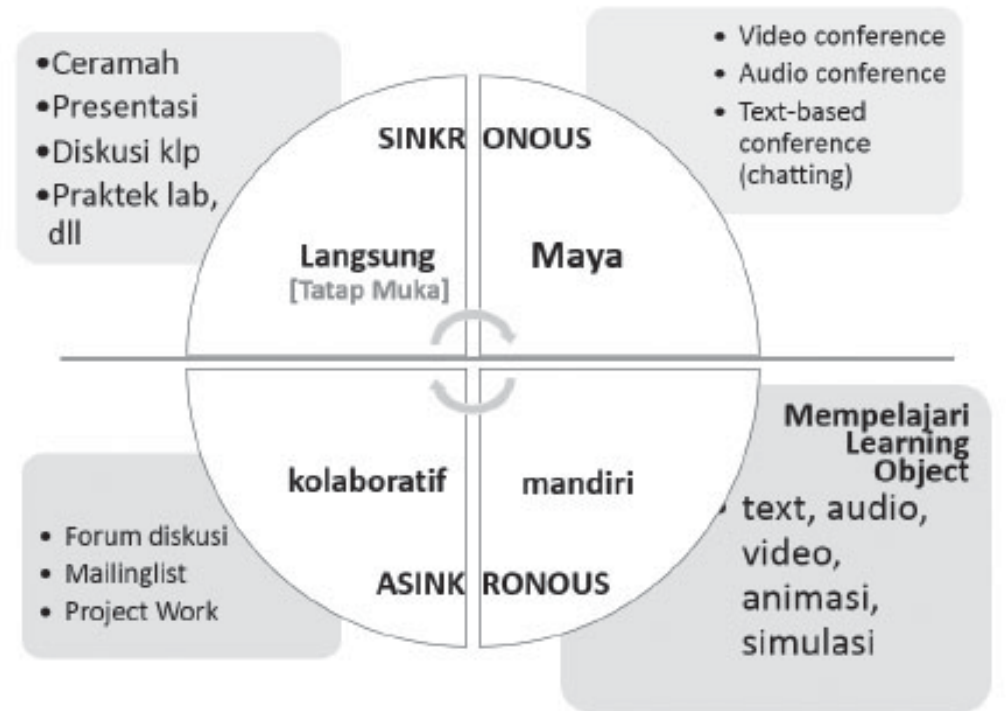


pembelajaran yang terjadi dalam konteks ini adalah presentasi, diskusi, demonstrasi, tutorial dan lain-lain menggunakan teknologi dan tool komunikasi seperti telewicara: video-conference, audio-conference, atau mungkin chatting (text-based conference).

Asinkronous Mandiri (Self-paced Asynchronous); suatu kondisi dimana belajar terjadi secara mandiri, kapan saja di mana saja sesuai dengan kondisi dan kecepatan belajarnya masing-masing. Dalam konteks ini, belajar terjadi tanpa terikat dengan waktu dan tempat. Sifatnya lebih terbuka dan luwes melalui metode belajar mandiri. Agar terjadi belajar mandiri, peserta belajar difasilitasi dengan bahan ajar digital yang dikenal dengan istilah learning object dalam beragam format media baik yang berbasis teks, audio, video, animasi, simulasi, permainan ataupun kombinasi dari semua itu (hypermedia).

Asinkronous Kolaboratif (Colaborative Asynchronous); suatu kondisi dimana belajar terjadi kapan saja dan di mana saja melalui kolaborasi antara dua orang atau lebih. Contoh metode pembelajaran yang terjadi dalam konteks ini adalah metode diskusi, tutorial dan tanya jawab melalui forum diskusi online, metode pemecahan masalah dan pembelajaran kolaboratif melalui penugasan online (online assignment).

\section{Strategi Pembelajaran dalam Kuadran Seting Belajar}

Jika kita kombinasikan antara klasifikasi strategi pembelajaran menurut Smaldino $d k k$. dan seting belajar menurut Noord, maka dapat dicontohkan seperti dalam tabel 4 .

Tabel 4: Kombinasi antara klasifikasi strategi pembelajaran

\begin{tabular}{|c|c|c|c|c|}
\hline \multirow{2}{*}{$\begin{array}{l}\text { Strategi } \\
\text { Pembelajaran }\end{array}$} & \multicolumn{3}{|c|}{ Seting Belajar } & \multirow[b]{2}{*}{$\begin{array}{c}\text { Asinkronous } \\
\text { Kolaboratif }\end{array}$} \\
\hline & $\begin{array}{l}\text { Sinkronous } \\
\text { Langsung }\end{array}$ & $\begin{array}{c}\text { Sinkronous } \\
\text { Maya }\end{array}$ & $\begin{array}{c}\text { Asinkronous } \\
\text { Mandiri }\end{array}$ & \\
\hline Presentasi & $\begin{array}{l}\text { Presentasi } \\
\text { dalam kelas }\end{array}$ & $\begin{array}{l}\text { Presentasi via } \\
\text { video conference }\end{array}$ & $\begin{array}{l}\text { Mempelajari } \\
\text { video presentasi }\end{array}$ & - \\
\hline Demonstrasi & $\begin{array}{l}\text { Demonstrasi dalam } \\
\text { kelas atau di } \\
\text { lingkungan } \\
\text { senyatanya }\end{array}$ & $\begin{array}{l}\text { Demonstrasi via } \\
\text { video conference }\end{array}$ & $\begin{array}{l}\text { Mempelajari } \\
\text { demonstrasi vis video }\end{array}$ & - \\
\hline Drill \& Praktek & $\begin{array}{l}\text { Drill dan praktek di } \\
\text { kelas, lapangan atau } \\
\text { tempat senyatanya }\end{array}$ & $\begin{array}{l}\text { Drill dan praktek } \\
\text { melalui game virtual } \\
\text { online }\end{array}$ & $\begin{array}{l}\text { Drill \& praktek melalui } \\
\text { game atau simulator }\end{array}$ & $\begin{array}{l}\text { Penugasan } \\
\text { (assignment) individu } \\
\text { maupun kelompok untuk } \\
\text { mempraktekkan } \\
\text { sesuatu. }\end{array}$ \\
\hline Tutorial & $\begin{array}{l}\text { Tutorial langsung } \\
\text { individual maupun } \\
\text { kelompok }\end{array}$ & $\begin{array}{l}\text { Tutorial via video } \\
\text { conference atau } \\
\text { audioconference }\end{array}$ & $\begin{array}{l}\text { Tutorial melalui forum } \\
\text { diskusi, e-mail, milist }\end{array}$ & - \\
\hline Diskusi & Diskusi dalam kelas & $\begin{array}{l}\text { Diskusi melalui video } \\
\text { conference, audio } \\
\text { cenference, atau } \\
\text { chatting }\end{array}$ & - & - \\
\hline $\begin{array}{l}\text { Permainan dan } \\
\text { SImulasi }\end{array}$ & $\begin{array}{l}\text { Permainan dan } \\
\text { simulasi dilingkungan } \\
\text { senyatanya }\end{array}$ & $\begin{array}{l}\text { Simulasi dan } \\
\text { permainan secara } \\
\text { virtual dan online }\end{array}$ & $\begin{array}{l}\text { Game dan simulator } \\
\text { online atau offline (CD } \\
\text { multimedia) }\end{array}$ & - \\
\hline $\begin{array}{l}\text { Pemecahan } \\
\text { Masalah }\end{array}$ & $\begin{array}{l}\text { Diskusi studi kasus } \\
\text { dalam kelas }\end{array}$ & $\begin{array}{l}\text { Diskusi dan tanya } \\
\text { jawab melalui video- } \\
\text { conference }\end{array}$ & - & $\begin{array}{l}\text { Penugasan untuk } \\
\text { memecahkan suatu } \\
\text { kasus, maslah baik } \\
\text { individu atau kelompok }\end{array}$ \\
\hline $\begin{array}{l}\text { Pembelajaran } \\
\text { Kooperatif }\end{array}$ & - & - & - & $\begin{array}{l}\text { Penugasan untuk } \\
\text { mengerjakan suatu } \\
\text { project tertentu }\end{array}$ \\
\hline
\end{tabular}




\section{Standar Proses Pembelajaran, Strategi Pembelajaran dan Kuadran Seting Belajar \\ Standar proses pembelajaran dalam konteks lingkungan e-learning, penulis klasifikasikan kedalam empat tahap, yaitu 1) tahap mempelajari (learning); 2) mendalami (deepening); 3) menerapkan (applying); dan}

4) menjajaki penguasaan (measuring). Empat tahap ini, penulis adaptasi dari tiga tahapan belajar menurut Horton, yaitu 1) absorb; 2) do; dan 3) enact. Penulis menambahkan satu tahap terkahir yaitu pengukuran hasil belajar. Standar proses pembelajaran tersebut dapat digambarkan pada diagram 2.

Diagram 2: Standard proses pembelajaran

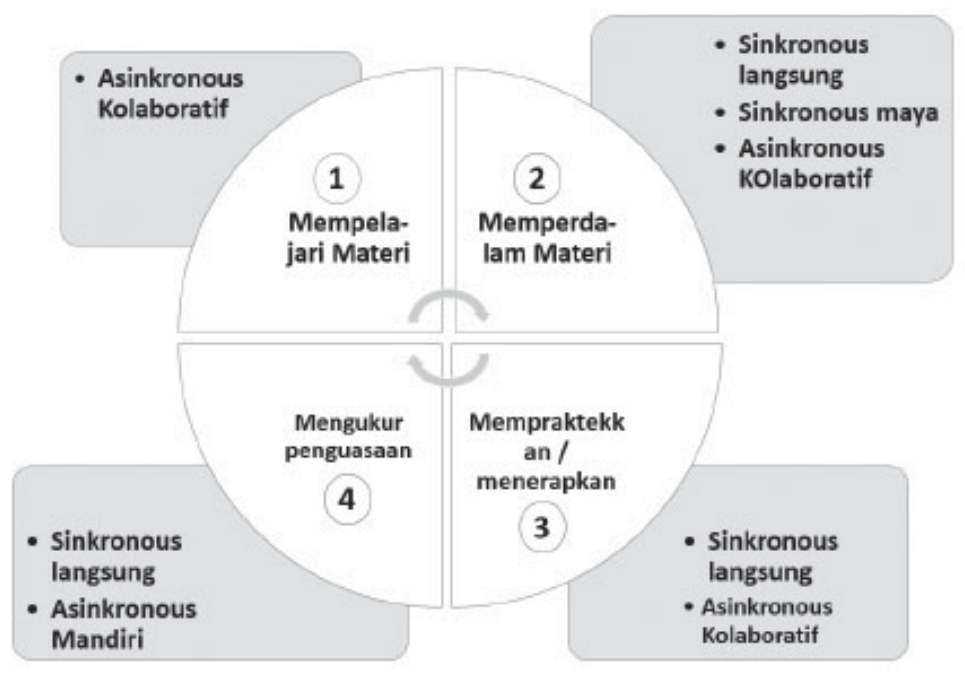

Hubungan antara empat tahapan belajar dengan strategi dan kuadran belajar dapat digambarkan seperti tabel 5.

Tabel 5: Hubungan antara empat tahapan belajar

\begin{tabular}{ll}
\hline Tahapan Belajar & Strategi dan Seting Belajar \\
\hline 1. Mempelajari & $\begin{array}{l}\text { Dapat dicapai melalui strategi presentasi dan demonstrasi yang dapat dipelajari secara mandiri } \\
\text { dalam seting asinkronous mandiri dengan cara mempelajari bahan ajar yang dikemas secara } \\
\text { digital dalam berbagai jenis dan format media. Sehingga dapat dipelajari kapan saja dan di mana } \\
\text { saja }\end{array}$ \\
\hline 2. Mendalami & $\begin{array}{l}\text { Dapat dicapai melalui strategi demonstrasi, drill \& practice dan tutorial baik dalam seting belajar } \\
\text { sinkronous langsung (demonstrasi dan praktek langsung), asinkronous mandiri (mempelajari } \\
\text { video tutorial atau drill \& prcatice online). }\end{array}$ \\
\hline 3. Menerapkan & $\begin{array}{l}\text { Dapat dicapai melalui strategi pemecahan masalah dan pembelajaran kolaboratif yang terjadi } \\
\text { dalam seting belajar sinkronous langsung maupun sinkronous kolaboratif (melalui penugasan). }\end{array}$ \\
\hline 4. Mengukur hasil belajar & $\begin{array}{l}\text { Dapat dicapai melalui strategi evaluasi hasil belajar yang dapat terjadi dalam seting belajar } \\
\text { sinkronous langsung (seperti performance assessment maupun pencl on paper test didalam } \\
\text { kelas) dan terjadi dalam seting belajar asinkronous mandiri (seperti mengerjakan test secara } \\
\text { online). }\end{array}$ \\
\hline
\end{tabular}


Dengan demikian, dalam merancang blended learning penulis menganjurkan untuk mempertimbangkan kuadran seting belajar dengan mengacu pada pemilihan strategi pembelajaran yang sesuai untuk mencapai suatu kompetensi tertentu yang hendak dicapai. Peluang implementasinya, bisa terjadi dalam konteks sinkronous langsung, sinkronous maya, asinkronous kolaboratif maupun asinkronous mandiri dengan segala tool dan teknologi informasi dan komunikasi yang relevan. Pertimbangan terakhir adalah situasi dan kondisi baik dari sisi peserta belajar maupun lembaga pendidikan. Sebagai contoh, untuk mencapai kompetensi, "Mahasiswa dapat menentukan metode dan media yang tepat untuk mencapai suatu tujuan pembelajaran tertentu", maka diperoleh beberapa kemungkinan seperti dalam tabel 6 .

Dari sekian banyak peluang tersebut, mengingat berbagai situasi dan kondisi, penulis memilih kombinasi blended learning Tabel 7.

Tabel 6: Metode dan media untuk mencapai tujuan pembelajaran

\begin{tabular}{|c|c|c|c|c|}
\hline \multirow{2}{*}{ Tujuan/Kompetensi } & \multicolumn{4}{|c|}{ Seting Belajar } \\
\hline & $\begin{array}{l}\text { Sinkronous } \\
\text { Langsung }\end{array}$ & $\begin{array}{c}\text { Sinkronous } \\
\text { Maya }\end{array}$ & $\begin{array}{l}\text { Asinkronous } \\
\text { Mandiri }\end{array}$ & $\begin{array}{c}\text { Asinkronous } \\
\text { Kolaboratif }\end{array}$ \\
\hline $\begin{array}{l}\text { Mahasiswa dapat } \\
\text { menentukan metode dan } \\
\text { media yang tepat untuk } \\
\text { mencapai tujuan } \\
\text { pembelajaran tertentu }\end{array}$ & $\begin{array}{l}\text { Problem solving } \\
\text { didalam kelas secara } \\
\text { kelompok memilih dan } \\
\text { menentukan metode } \\
\text { dan media yang tepat } \\
\text { terhadap beberapa } \\
\text { tujuan pembelajaran } \\
\text { tertentu yang diberikan }\end{array}$ & $\begin{array}{l}\text { Mendiskusikan } \\
\text { kasus-kasus } \\
\text { penentuan metode } \\
\text { dan media untuk } \\
\text { mencapai tujuan } \\
\text { pembelajaran } \\
\text { tertentu melalui } \\
\text { video conference }\end{array}$ & $\begin{array}{l}\text { Mempelajari } \\
\text { contoh-contoh } \\
\text { metode dan } \\
\text { media yang tepat } \\
\text { untuk tujuan } \\
\text { pembelajaran } \\
\text { tertentu dalam } \\
\text { bentuk text (pdf) }\end{array}$ & $\begin{array}{l}\text { Mengerjakan tugas } \\
\text { indvidu menentukan } \\
\text { metode dan media } \\
\text { yang tepat untuk } \\
\text { mencapai tujuan } \\
\text { pembelajaran tertentu } \\
\text { yang telah ditentukan. }\end{array}$ \\
\hline
\end{tabular}

Tabel 7: Kombinasi blended learning

\begin{tabular}{lll}
\hline Tujuan & Strategi & Seting Belajar \\
\hline $\begin{array}{l}\text { Mahasiswa dapat } \\
\text { menentukan metode } \\
\text { pembelajaran yang }\end{array}$ & $\begin{array}{l}\text { 1. Presentasi } \\
\text { 2. Praktek pemecahan } \\
\text { tepat sesuai dengan } \\
\text { tujuan yang ingin } \\
\text { dicapai }\end{array}$ & $\begin{array}{l}\text { Sinkronous Langsung: Studi kasus dalam } \\
\text { kelasSinkronous Maya: -Asinkronous Kolaboratif }\end{array}$ \\
& $\begin{array}{l}\text { Assignment: tugas kelompok (@diberikan beberapa kasus } \\
\text { tujuan pembelajaran yang hendak dicapai) Asinkronous } \\
\text { Mandiri Mempelajari bab 3: stragi pembelajaran dalam bentuk }\end{array}$ \\
\hline
\end{tabular}

\section{Simpulan dan Saran \\ Simpulan}

Peristiwa mengalami adalah kunci dari proses yang dinamakan belajar. Oleh karena itu, e-learning pada dasarnya adalah memfasilitasi terjadinya pengalaman belajar yang optimal dengan memanfaatkan secara tepat teknologi informasi dan komunikasi yang sesuai untuk mencapai tujuan pembelajaran yang hendak dicapai. Pengalaman belajar tersebut dapat diupayakan melalui dua kontinum strategi pembelajaran yaitu: 1) pembelajaran yang berorientasi pada guru (seperti tutorial, presentasi, demonstrasi, dll.) dan pembelajaran yang berorientasi pada sisiwa (seperti diskusi, permainan, pembelajaran kolaboratif, pembelajaran kooperatif, dII.). Dalam konteks e-learning, pengalaman belajar tersebut dapat dioptimalkan dengan empat standar proses pembelajaran yaitu: 1) mempelajari (learning); 2) mendalami (deepening); 3) menerapkan (applying); dan 4) mengukur keberhasilan belajar (measuring). Semua hal tersebut dapat difasilitasi 
dengan pemanfaatan TIK secara tepat dalam empat kuadran seting belajar, yaitu: 1) sinkronous langsung; 2) sinkronous maya; 3) sinkronous mandiri; dan 4) sinkronous kolaboratif. Empat unsur tersebut dapat dijadikan sebagai framework dalam merancang blended learning yang tepat.

\section{Saran}

Mengacu pada kerangka kerja (framework) seperti dijelaskan di atas, maka dalam merancang blended learning, disarankan untuk mempertimbangkan beberapa hal sebagai berikut:

Memahami benar bahwa esensi belajar adalah mengalami. Oleh karena itu, fokus utama merancang e-learning, termasuk didalamnya blended learning adalah memfasilitasi terjadinya pengalaman belajar secara optimal dengan memanfaatkan strategi pembelajaran dan teknologi informasi dan komunikasi yang tepat.

Untuk mencapai tujuan tersebut, disarankan untuk melakukan beberapa langkah sebagai berikut: (a) Perhatikan rumusan tujuan pembelajaran atau kompetensi yang hendak dicapai; (b) Mengacu pada tujuan pembelajaran atau kompetensi yang ingin dicapai tentukan strategi pembelajaran yang tepat menggunakan dua kontinum strategi pembelajaran seperti dijelaskan di atas sebagai patokan; (c) Mengacu pada tujuan pembelajaran atau kompetensi serta strategi pembelajaran yang telah dipilih, dengan menggunakan empat standar proses pembelajaran dan empat kuadran seting belajar dan seperti dijelaskan di atas, pilih dan tentukan: (1) untuk tahap mempelajari (learning), dapat dicapai dalam seting belajar dan teknologi informasi dan komunikasi yang tepat seperti apa sesuai dengan kondisi dan situasi dari sisi pemelajar maupun lembaga pendidikan terkait?; (2) untuk tahap mendalami (deepening), dapat dicapai dalam seting belajar dan teknologi informasi dan komunikasi yang tepat seperti apa sesuai dengan kondisi dan situasi dari sisi pemelajar maupun lembaga pendidikan terkait? (3 ) untuk tahap menerapkan (applying), dapat dicapai dalam seting belajar dan teknologi informasi dan komunikasi yang tepat seperti apa sesuai dengan kondisi dan situasi dari sisi pemelajar maupun lembaga pendidikan terkait? (4) untuk tahap mengukur pencapaian hasil belajar (measuring), dapat dicapai dalam seting belajar dan teknologi informasi dan komunikasi yang tepat seperti apa sesuai dengan kondisi dan situasi dari sisi pemelajar maupun lembaga pendidikan terkait?

Tuangkan hasilnya ke dalam format silabus. Setelah semua selesai, tuangkan semuanya kedalam silabus utuh dan jadwal perkuliahan yang akan dilaksanakan selama satu semester.

\section{Pustaka Acuan}

Bonk, C. J. \& Graham, C. R., 2006. the Handbook of Blended Learning: Global Perspective, Local Design. San Fransisco, California, USA: John Wiley and Sons, Inc.

Dabbagh , N. \& Ritland, . B. B., 2005. Online Learning: Concepts, Strategies and Application. New Jersey, USA : Merril Prentice Hall, Pearson Education Inc.

Holmes, B. \& Gardner, . J., 2006. E-Learning: Concept and Practice.. London, California, New Delhi: Sage Publication Ltd.

Horton, W., 2006. e-Learning by Design. San Fransisco, CA: Pfeiffer: John Wiley \& Sons, Inc..

Howard , L., Remenyi, Z. \& Pap, G., 2006. Adaptive Blended Learning Environment. Nashville, 9th International Conference on Engineering Education, Institute for Software Integrated Systems.

Khan, B., 2005. Managing e-Learning Strategies: Design, Delivery, Implementation and Evaluation. USA: Idea Group Inc. .

Khan, B., 2005. Managing e-Learning Strategies: Design, Delivery, Implementation and Evaluation. USA: Idea Group Inc..

Littlejohn, A. \& Pegler, C., 2007. Preparing for Blended e-Learning. New York, USA: Routledge.

Naidu, S., 2006. e-Learning: a Guidebook of Principles, Procedures, and Practices. Revision Edition penyunt. 
New delhi: Commonwealth Educational Media Center .

Noirid, S., 2007. "E-learning Models: A Review of Literature". The 1st International Conference on Educational Reform November 9-11, 2007. Bangkok, s.n.

Piskurich, G. M., 2006. Rapid Instructional Design: Learning ID Fast and Right (Second Edition). San Fransisco, CA: Pfeiffer, John Wiley and Sons, Inc. .

Smaldino, S., Lowther, D. \& Russel, J., 2008. Instructional Technology and Media for Learning. Ninth Edition penyunt. Upper Saddle River, New Jersey, USA: Perason Prentice Hall, Pearson Education, Inc..

Staley, L., 2007. Where Mind Meet. [Online] Available at: http://wiki.carr.org/db/share/ onlinesupervisorwiki/Project/ Archive/Examples/How/to/Blend/12475/Blended/Learning/Guidefrom/WJ.pdf

Staley, L., 2007. Where Mind Meet. [Online] Available at: http://wiki.carr.org/db/share/ onlinesupervisorwiki/Project/ Archive/Examples/How/to/Blend/12475/Blended/Learning/Guidefrom/WJ.pdf.

Stockley, D., 2010. e-Learning Definition and Explanation. [Online] Available at: http://www.derekstock ley.com.aud [Diakses 19 February 2010].

Thorne, K., 2003. Blended learning : How to Integrate Online and Traditional Learning. London, UK and USA: Kogan Page Limited.

Watson, J., 2008. Blended Learning: Convergence between Online and Face-to-Face Education. USA: North American Council for Online Learning. 